\title{
Sound and Sense - A Musical Look at Chinese Poetry in 1916
}

\author{
You sit, chanting the maxims of Confucius. \\ On your head is a domed cap of black satin and your supple hands \\ with their long nails are piously folded. \\ You rock to and fro rhythmically. \\ Your voice, rising and falling in clear nasal monosyllables, flows \\ the flowering of thought. \\ on steadily, monotonously, like the flowing of water and \\ You are chanting, it seems, of the pious conduct of man in all ages, \\ And I know you for a scoundrel. \\ None the less the maxims of Confucius are venerable, and your \\ voice pleasant. \\ I listen attentively......
}

Zeb Raft

University of Alberta

Eunice Tietjens, “A Scholar”, 1916

"Sound and sense"

This axiom of twentieth century pedagogy poses a distinct problem when it comes to dealing with poetry in translation. In the early twentieth century, when Chinese poetry made its first permanent mark on Western readers and writers, we find the relationship of sound and sense negotiated in various ways. Earliest was the naïve solution advanced, for instance, by Herbert Giles (1845-1935) in his Chinese Poetry in English Verse (1898), which attempts to make a happy marriage of the Chinese sense (more or less) with the sounds of a conventional Victorian prosody. This solution produced dignified and readable results, but it also led to some curious choices, as when, to cite one infamous example, Giles converted the Chinese word for "wall" into the English word "sky" - in order to provide a rhyme for "Goodbye!"1

\footnotetext{
${ }^{1}$ See Yip, Eqra Pound's Cathay, p. 16. If Giles's liberty seems egregious, it might be pointed out that there is a certain contiguity of association between "wall" (as in "great wall") and "sky", both of which can represent the limits of a civilized community. The poem in question is Li Bai’s "Sending off a Friend" ("Song youren” 送友 人), translated as “A Farewell” in Giles, Chinese Poetry, p. 70.
} 
TranscUlturAl, vol.1.3 (2010), 94-112.

http://ejournals.library.ualberta.ca/index.php/TC

Giles and other scholars of his age translated Chinese poetry into what it 'should sound like' in English, but with the advent of what we now know as modernism came the question, 'what should poetry sound like’? For Ezra Pound (1885-1972), whose Cathay poems (1915) were liberal renditions based on the word-for-word notes and commentary of Ernest Fenollosa (1853-1908), this meant dropping, in a deft combination of willfulness and ignorance, the sense of the Chinese original and replacing it with a soundscape of his own signature:

Sorrow to go, and sorrow, sorrow returning,

Desolate, desolate fields,

And no children of warfare upon them,

No longer the men for offence and defence. (Pound 16-17)2

Arthur Waley (1889-1966), by contrast, drew on the possibilities of the new "free verse" but in reaction to Pound. His eminently intelligible and generally fairly accurate representations of the sense of Chinese poetry take shape in a form that sounds as much like modest prose as it does poetry:

Those who are happy regret the shortness of the day;

Those who are sad tire of the year's sloth.

But those whose hearts are devoid of joy or sadness

Just go on living, regardless of "short" or "long." (Waley 150) ${ }^{3}$

In this essay, I wish to introduce one lesser-known negotiation of the sound and sense of Chinese poetry - or of China - in the modernist era, one that technically falls outside the realm of translation but provides a useful commentary on the nature of Chinese poetry in translation in the early twentieth century. Eunice Tietjens (1884-1944) was active on the Chicago poetry scene in the 1910s, becoming an associate editor of Harriet Monroe's journal, Poetry: A Magazine of Verse (1912-present), in 1916. In 1915 - the year in which Poetry

\footnotetext{
${ }^{2}$ The quotation here, from Pound's translation of the fourteenth poem in Li Bai's "Gufeng” 古風 series, is characteristically unrepresentative of the sense of the original. For a discussion of Pound's version, see Xie, Eqra Pound and the Appropriation of Chinese Poetry, pp. 105-07.

${ }^{3}$ The quotation is from Bai Juyi’s “After Lunch" (“Shi hou” 食後).
} 
TranscUlturAl, vol.1.3 (2010), 94-112.

http://ejournals.library.ualberta.ca/index.php/TC

published the first of Pound's Cathay poems - Tietjens embarked on a trip to the Far East, making half year stays in Japan and China. Her time in China was, she recalled in a memoir twenty years later, "an experience that altered my whole outlook on life, so that I was never afterwards quite the same person" (World 70). It provoked two works of poetic significance: a short article on the recitation of Chinese poetry by native scholars, appearing in the October 1916 issue of Poetry, and a series of her own travelogue poems, a selection of which were published in the December issue, with the full group appearing in book form the following year. With these two endeavours, we find Tietjens addressing, respectively, the sound and the sense of Chinese poetry in her time.

\section{Sound}

Tietjens's visit to China, in the company of her mother, her sister Peggy, and her eightyear-old daughter Janet, included the usual destinations of western visitors (Shanghai, Peking, Hong Kong), but her main experience was in the city of Wuxi, where her sister Louise was an Episcopal missionary. Wuxi is only a hundred-some kilometers inland from Shanghai, but to Tietjens it was truly China's "interior", far from the westernized culture of the treaty ports. A city of 200,000 Chinese, plus eight westerners: "Our advent brought the white population to twelve" (World 104).

Surrounded, indeed overwhelmed, by the sounds and sights of an alien culture, it may not be surprising that Tietjens sought some intuitive way of approaching Chinese culture. As a poet herself, she was interested in poetry. Moreover, Far Eastern poetics had been a regular presence in the run up to imagism and modernism, and Chinese poetry in particular took on a new importance when Pound reintroduced it with his Cathay poems. ${ }^{4}$ Tietjens would

\footnotetext{
4 The relationship of Chinese poetry to modernism has been central to several fine recent studies, including Qian 1995 and 2003, Kern 1996, Xie 1999 and Huang 2002.
} 
TranscUlturAl, vol.1.3 (2010), 94-112.

http://ejournals.library.ualberta.ca/index.php/TC

certainly have been curious about Chinese poetry. Yet she knew little, if any at all, of the language.

The result was an intriguing experiment with the sound of Chinese poetry as it was recited by traditional Chinese scholars. In "The Chinese Chanting of the Classics", Tietjens begins with reference to Yeats's account of chanting by early Irish bards. She then notes that an analogous practice of chanting exists to the present day in China, and she proposes, with the help of her sister Peg, who was a cellist of some renown, to put this chanting style into musical notation. ${ }^{5}$ A short poem is selected (or chanced upon - she offers no circumstantial detail) and chanted by two different scholars, producing two versions for comparison. Here is the poem, "Spring Night", a quatrain by the famous Song dynasty poet Su Shi (1037-1101). The accompanying translation is my own. Beneath the Chinese characters are the Chinese sounds as Tietjens's article transcribes them, in an unorthodox system presumably reflecting the local dialect.

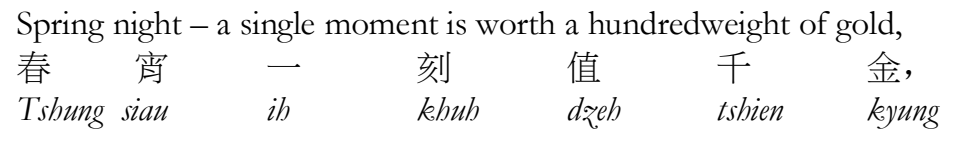

春宵一刻值金,

The flowers offer clear fragrance, the moon its shade.

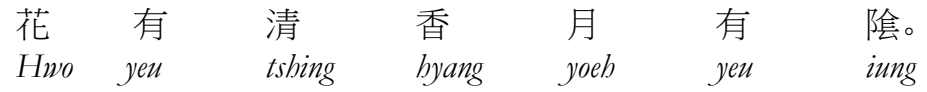

Song and flutes from the upper stories - their sound delicate, so delicate,

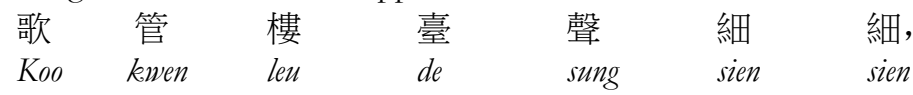

The swing in the courtyard - the night sinks, sinks away.

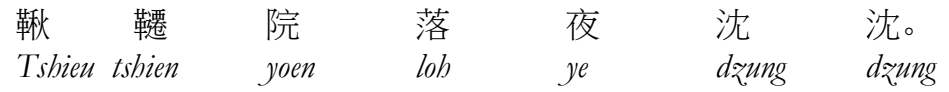

"The general effect," she writes, “... is clear and nasal in quality, with the soft yet nasal $n g$ sound of the French language very much in evidence" ("Chinese Chanting" 39).

\footnotetext{
${ }^{5}$ Followers of twentieth century popular music may be interested to know that the family's greatest musical contribution came from their younger brother, Laurens Hammond, who invented the "Hammond organ" in 1934.
} 
TranscUlturAl, vol.1.3 (2010), 94-112.

http://ejournals.library.ualberta.ca/index.php/TC

Tietjens's musical notation for the two poems is reprinted at the end of this section (Figure 1). I encourage the reader to find an instrument on which to sound the melodies out, to hear the sound Eunice Tietjens heard, and in particular to hear the surprising contrast between the two versions, which I will try to describe in words here. Though I am unable to offer a truly competent musicological analysis, I do think it worthwhile to try, noting the connections between the music and poem. [Readers, please click on "supplementary files" under Reading Tools at the right side of your screen to access the sound files that offer rough approximations (editor's note)].

The first tune possesses an angular beauty, tinged with melancholy, a feeling that is entirely suitable to this poem. The first line opens with an E-flat major triad, voicing the poem's theme ("a single moment of a spring night"), but the true quality of the tune becomes apparent when the second bar (also the second half of the poetic line) suddenly introduces what would be an augmented fifth (a B), on the word "is worth" (dzeb). Indeed, this slight incongruity prompts us to ask, what is a fine spring night worth?

The second line then starts on this augmented fifth, moving in whole steps through the augmented sixth and on to the tonic E-flat in the upper octave, then back down the sequence to the tonic in its original position. This brings us through half of the line - "the flowers offer [literally, 'have'] their fragrance". The second half - "the moon offers ['has'] its shadow" - is essentially raised a half step - an augmented third (G-sharp), augmented fifth (B), and back to the augmented third, as if the key had shifted from E-flat to E. This is effective because the two halves of the poetic line are an exact pair, and if set in a simple and continuous melody they would be perceived statically. Instead, the musical shift reflects the dual framing at work here, the fragrance set off by the soft moonlight and the moonlight 
TranscUlturAl, vol.1.3 (2010), 94-112.

http://ejournals.library.ualberta.ca/index.php/TC

softened by the scent of spring flowers. This draws out the ethereal sensation of the diaphanous shadows one sees under moonlight.

The third and fourth lines, which are parallel in their semantic structure, continue to play on the whole step figure established in line two. The most prominent distinction of the third line is the way it closes on the upper octave tonic, as if the words "delicate, so delicate" were rising up to meet something just so. This high delicacy is left hanging in the air, and then inverted with a low octave tonic at the start of the fourth line. There, the courtyard swing, an object with romantic connotations, ${ }^{6}$ rises up - again to the upper octave tonic - and swings back down again, "sinking away" into the lower registers of the night.

In its parts and in the whole, the sounds Tietjens has transcribed - or rather created, since this is a "sung" approximation of what the "chanting" sounded like to her - capture something essential about the poem. The musical line has the poem's 'delicacy', the absence of a true key reflects its odd 'shadows', and the subdued ending captures the poem's touch of melancholy, as a witness not just to a delicate moment but to its 'sinking away' with the passage of time.

The second tune comes entirely unexpectedly, at least to this listener. It is an attractive melody, but in an entirely uncomplicated fashion, completely devoid of the alluring peculiarity one finds in the first tune. In pure E-major, ${ }^{7}$ straying not even once from the pentatonic scale, the second tune is stately and pleasant but lacks the strong flavors of the first. If an analogy might be drawn to composers from (roughly speaking) the modernist era, the pensive melodic line of the first tune might have come from the palette of Paul Hindemith, while the four-square euphony of the second is like a folk melody from the hand

\footnotetext{
6 The translation of the poem provided by Tietjens mistakenly associates the swing with the play of children.

7 The score is marked A-major, but only because no D\# occurs in the melody.
} 
TranscUlturAl, vol.1.3 (2010), 94-112.

http://ejournals.library.ualberta.ca/index.php/TC

of Aaron Copland. The second tune could even be sung in round (like "Row, Row, Row Your Boat").

We might speculate that the scholar chanting the second version had a simpler sense of harmony than the first, or even that he possessed an insufficiently nuanced worldview, rendering him incapable of appreciating the poem's 'shadows' in his chant. Another explanation, however, lies in the direction of the tunes' true authors. The first tune is the product of a sustained effort, Tietjens and her sister bending their ears and minds around the sounds of an unfamiliar language and attempting to record something new to them. But China was hard on Tietjens. As she later recalled the impact of the experience:

I have seen my sister Peg, usually a most self-controlled person, come home after a walk of an hour or so ... to cast herself face downward shaken with sobs, from sheer nervous exhaustion. And if I did not do so myself I often yearned to. (World 103)

The second tune was surely easier on the sisters' ears. Perhaps it was the sound of a Chinese poem as it was heard by an exhausted audience. 
TranscUlturAl, vol.1.3 (2010), 94-112.

http://ejournals.library.ualberta.ca/index.php/TC

Figure 1: Eunice Tietjens's musical representation of Chinese poetry

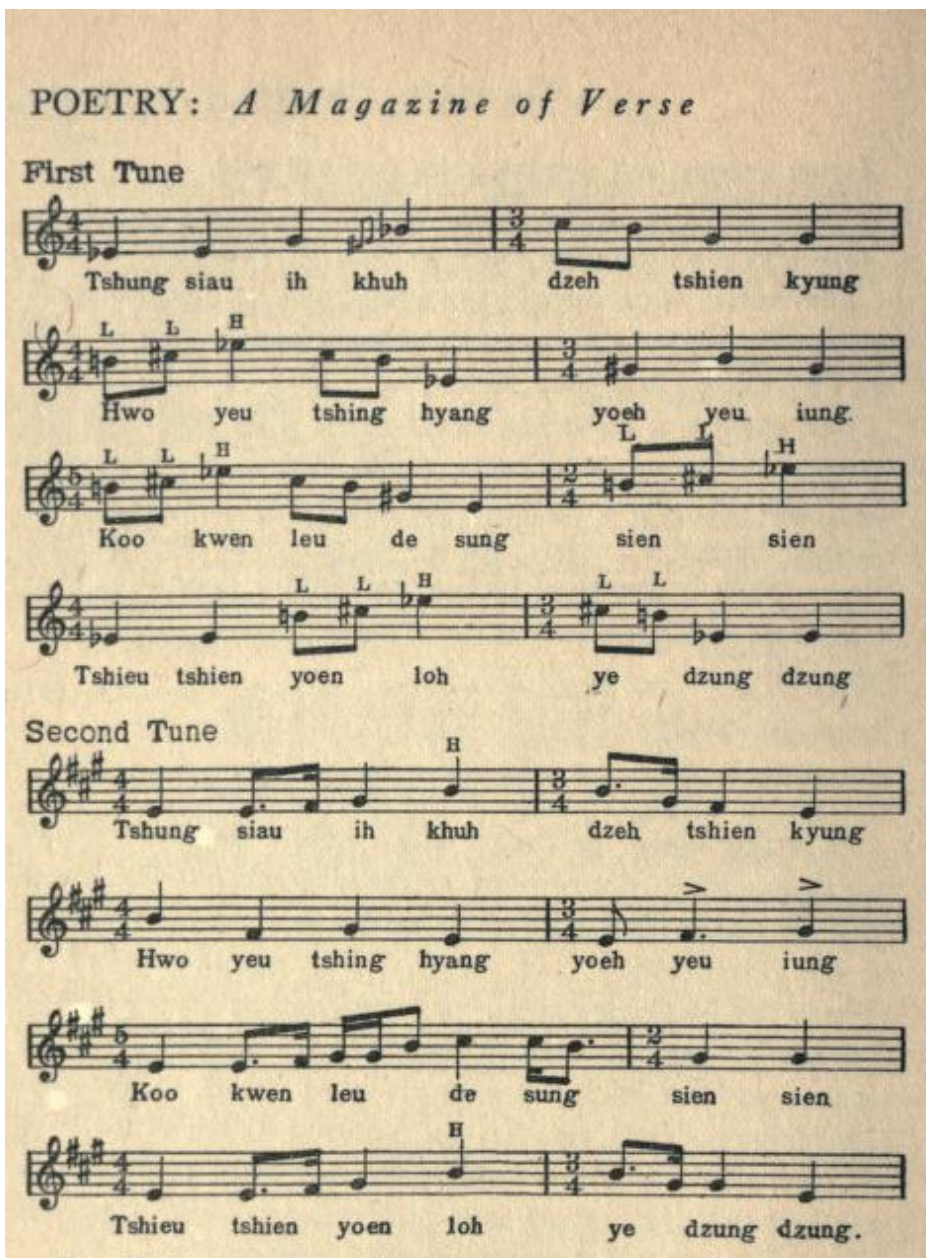

Poetry: A Magazine of Verse, Vol. 9, October 1916. Source:

http://www.archive.org/stream/poetrymag09monruoft\#page. The "H"s and "L"s in the notation indicate notes bent upwards or downwards.

Sense

I would suggest, then, that the first musical transcription of the poem was a genuine creative attempt at preserving the alterity Tietjens found in China, while the second was a retreat from this sensation into a simpler and more familiar musical world. Nevertheless, it is beyond doubt that the former is the effect Tietjens was seeking when she presented her musical transcriptions to the audience of Poetry. Her essay closes with the following words: 
TranscUlturAl, vol.1.3 (2010), 94-112.

http://ejournals.library.ualberta.ca/index.php/TC

It is interesting to think of the probable effect on an Anglo-Saxon audience of reciting one of our own classical lyrics, say Herrick's To Daisies, not to shut so soon, in this oriental fashion. The "closeness of the Chinese soul", of which Carl Sandburg writes so assuredly, has decidedly its limitations. ("Chinese Chanting"

The internal quotation here is from the strident defense of Ezra Pound by Carl Sandburg that had appeared in Poetry half a year earlier. Reading the Cathay poems, Sandburg wrote, "[o]ne realizes the closeness of the Chinese soul as a next-door human neighbor, fellowtraveler on an old, old planet" (Sandburg 253). Tietjens is not so much criticizing Pound as taking issue with the romantic, even glib enthusiasm with which Chinese poetry tended to be received by her contemporaries. Her experiment with musical representation of the "sounds" of Chinese poetry was one attempt to give some precision to the western experience of Chinese poetry, which in her view was to be a hard journey. She would attempt a similar intervention on the level of "sense".

Not understanding the language, Tietjens was not capable of directly addressing the sense of Chinese poetry itself (though such a constraint had not really stopped Pound), but she could make use of her own poetic sensibilities to represent the "sense" of China. The results were published in book form in 1917 under the title of Profiles from China, which she later characterized as "a series of sketches in free verse of people and things I had actually seen and smelled and tasted", adding that they were written "with scrupulous integrity", providing "vivid pictures" of her time in China (World 101-2). The poems in Tietjens's Profiles may not qualify as good poetry, but they do convey one of poetry's inherent goods, the direct yet artful expression of a poet's feelings.

Unfortunately, in this case the poet's feelings are rather unpleasant. "The Hand", the "proem" which serves as an introduction to her book, offers a good example of what we are faced with here, a litany of cultural stereotypes ranging between offensive and embarrassing. 
TranscUlturAl, vol.1.3 (2010), 94-112.

http://ejournals.library.ualberta.ca/index.php/TC

Staring at the hand of a Chinese man, Tietjens finds "a microcosm, the vast and shadowy Orient": "Very skilful is your hand", she writes, for "with a tiny brush it can feather lines of ineffable suggestion", or "carve strange dreams in ivory and milky jade" - thus she finds the Orient of exotic beauty. "And cruel is your hand", she continues, for "with the same cold daintiness and skill" it uses in the arts, so "it can devise exquisite tortures, eternities of incredible pain" - thus she finds the Orient of inhuman savagery. "Voluptuous is your hand", for "delicately it can caress a quivering skin, softly it can glide over golden thighs" thus the Orient of forbidden eroticism. The man's hand is "the hand of a woman" - thus the Orient in its feminine essence. But it is also "the paw of a chimpanzee" - thus the Orient primitive and beastly. "The room is full of strange shadows", the poem closes: "I am afraid of your hand....." - thus the latent menace of the Orient's many mysteries (Profiles 11-12).

Without attempting a complete rehabilitation, a few points of contextualization may allow us to rescue Tietjens's poetry from itself. To begin with, the age in which Tietjens wrote was thoroughly polluted with racialist ideas and stereotypes, making it natural, if not exactly excusable, for her perceptions to take shape within those well-worn ways. Whether she is writing of "witchery" in the eyes of an "inscrutably alien" Chinese woman (Profiles 34-5), of the "slit" eyes of a Chinese judge (his 'oriental dignity' notwithstanding) (73-5), or of a local coolie resting by his cart ("If he had ever seen a zoological garden I should say he was imitating the monkeys there. / As he has not, I dare say the taste is ingrained") (31), she may be faulted primarily for failing to rise above, or step outside of, the cultural constraints of her day. Moreover, if we can look past such descriptions, the account of China given by Tietjens was not altogether inaccurate. China of the late nineteenth and early twentieth century suffered from acute poor governance and harsh shocks to its traditional social structure, and Tietjens testifies to legitimate social ills that must have seemed all the more shocking to 
TranscUlturAl, vol.1.3 (2010), 94-112.

http://ejournals.library.ualberta.ca/index.php/TC

someone coming from the heart of Chicago's progressive movement, where less extreme versions of the hardships she describes - factory conditions, abject poverty, gender discrimination - were receiving far more vigorous redress. The great mistake made by many outside (and even native) observers of China lay in making generalized diagnoses of the inherent ills of Chinese civilization based on difficulties specific to this particular time of hardship. Tietjens, by and large, can be said to have avoided this pitfall.

Tietjens's China experience was also affected by the antagonistic relationship of the two cultures at this time. Blame for this may be fairly assigned to western imperialism, but this does not change her personal experience of the tensions of the time. A poem entitled "The Bridge", for instance, recounts a would-be leisure outing on the canal system to a village in the surrounding countryside. Here is what happens when they pass beneath a certain "Bridge of the Eight Scholars", which Tietjens has deemed "pleasing to the eye":

On the bridge the village is assembled. Foreign devils are a rarity.

The gold-brown faces are not unfriendly, merely curious. They peer in rows over the rail with grunts of nasal interest.

Tentatively, experimentally, as we pass they spit down upon us. Not that they wish us ill, but it can be done, and the temptation is too great. (23)

This is not the sort of experience that would endear one to Chinese culture. Yet virtually the same words could be summoned to describe, metaphorically, the treatment of the Chinese at the hands of many western writers of this day, and Tietjens, to her credit, exhibits a good deal of self-awareness here. In a poem called "Sunday in the British Empire: Hong Kong", she focuses, dripping with irony, on a rifle resting on a church pew as its owner attends a Sunday service extolling "God ... the author of peace and lover of concord" (62), and throughout her writings she speaks disparagingly of the assumptions of western superiority she witnessed in the treaty ports. 
TranscUlturAl, vol.1.3 (2010), 94-112.

http://ejournals.library.ualberta.ca/index.php/TC

Moreover, Tietjens also shows dissatisfaction with what she has been led to write in her own poems, cognizant that in many of these sketches it may seem that she is 'spitting' on the Chinese she describes. In a poem occasioned by a ride in a rickshaw (a two-wheeled carriage pulled by a human), she is disconcerted to find herself likening the runner's ears to those of a horse, and she comments:

I grow insufferably superior and Anglo-Saxon.

I am sorry, but what would you?

One is what one is. (58)

"One is what one is". It is this spirit, I think, that truly redeems the poems in Profiles from China. While it is true that cultural biases were more pronounced in Tietjens's era, the true target of Tietjens's raw accounts of her China experience was the segment of western culture that tended to idealize and patronize China and her glories, those advocates of "the closeness of the Chinese soul". These people were hardly in the habit of describing the Chinese as primitive monkeys, and when Tietjens did so, she was not so much repeating cultural stereotypes as striking out at the passivity of her immediate readership. If the soul of Chinese civilization is so close at hand, she is asking, then why would I have such a viscerally adverse reaction to it? Would your reaction be so different?

Put another way, in her poems Tietjens honestly gave her own "sense" of China, as opposed to the idealized sense her contemporaries - hear Pound here - so frequently found there, especially in Chinese poetry. This fact is well recognized in a somewhat airy but nevertheless perceptive review of Tietjens's book, also in Poetry, by the Imagist poet Amy Lowell (1874-1925). Lowell praises Tietjens's work for having shown "not the orient ... but the occidental reaction to the orient". She declares that the poems in Profiles from China are not "mere imitations of Chinese effects" (of which, some might say, Lowell herself was guilty), but rather "a real speech sprung out of experience". Praising Tietjens's "complete 
TranscUlturAl, vol.1.3 (2010), 94-112.

http://ejournals.library.ualberta.ca/index.php/TC

sincerity", Lowell continues: "As interpretations of Chinese character, these poems are only of the slightest interest; it is as pictures of the fundamental antagonism of the East and the West that they are important" (328). Reference to "fundamental antagonism" runs close to hyperbole, but Lowell does appear to have grasped the essence of Tietjens's poetic experiment:

In this age of adulation of all things oriental, it is well to meet so fearless an observer as Mrs. Tietjens. [...]

She sees, but only partially comprehends. [...] She understands, and yet - not quite. (329)

This is praise, not criticism. To use our terminology, Tietjens senses the Orient, and her selfawareness enables her to realize that she senses it only partially, "not quite". The poems are a record of how she honestly 'made sense of' an imperfect sensory experience.

With this understanding of Tietjens's enterprise, we may look more closely at the first five poems to appear in print, in the December 1916 issue of Poetry. The first is called "The Story Teller". "In the corner of the market place he sits", she begins, "his face the target for many eyes". The crowd is fixated as he tells his story, and Tietjens follows their attention, describing the storyteller's face, before wondering " $[\mathrm{w}]$ hat strange tale lives in the gestures of his mouth":

Does a fox-maiden, bewitching, tiny-footed, lure a scholar to his doom? Is an unfilial son tortured of I cannot tell. devils? Or does a decadent queen sport with her eunuchs?

The faces of the people are wooden; only their eyes burn dully with a reflected light.

I shall never know.

I am alien ... alien. (Profiles 18-19; ellipsis original) ${ }^{8}$

Thus the poem ends. The possible stories she enumerates (the fox-maiden, the wayward scholar, the venal eunuchs) represent some of the standard stereotypes of oriental exoticism, but she pointedly remains silent, as what she observes remains to her only "wooden" and

\footnotetext{
${ }^{8}$ Here and below I cite the poems from their book form, rather than from the original appearance in Poetry. The texts differ only in very minor matters of punctuation.
} 
TranscUlturAl, vol.1.3 (2010), 94-112.

http://ejournals.library.ualberta.ca/index.php/TC

"reflected", never living and direct. It is not that she finds the culture exotic, or "alien", but that she herself is alien to it. The poem closes with that word echoing in her mind.

The second poem, "Our Chinese Acquaintance", is largely in the voice of the title figure. "We met him in the runway called a street", she begins, "between the warrens known as houses. / .. / About him we felt a troubled uncertainty" (36). ${ }^{9}$ Shooing away the throngs that have gathered around them in the street, the Chinese gentleman relates to the western visitors how he had been in Belgium, "studying Christianity", when the War forced him home. He laments: "China is very dirty... Our priests are rascals, and the people.... I do not know" (37; ellipses original). Garbed in western attire, he is described as an "alien" presence amidst this dirt, and the poem ends with him repeating the words "I do not know". Tietjens's loss of bearings in China is an affliction even a displaced native might suffer from.

The next poem, "A Scholar", is worth quoting in full, and I have done so in the epigraph to this paper, placing it there because this poem's special effect loses some of its power after one has become familiar with Tietjens and the problem of perception she is dealing with in these poems. Read in minimal context, as it was by the subscribers to Poetry, the sudden jump from the "maxims of Confucius" (idealized in Europe as well as China) to the "scoundrel" doing the chanting is a striking comic and ironic turn. The irony is carried out icily through the final lines, and there is no clear indication as to how we should read them:

None the less the maxims of Confucius are venerable, and your voice pleasant.

I listen attentively.... (17; ellipsis original)

Can the maxims of Confucius really remain "venerable" in the hands of scoundrels? Have the scoundrels not sullied them at all? And can a 'pleasant voice' really be dissociated from its disingenuousness?

\footnotetext{
${ }^{9}$ In its opening lines and in the setting of a random meeting in the streets this poem curiously resembles a Chinese ballad, but I am not able to say what Chinese poem might have influenced Tietjens.
} 
TranscUlturAl, vol.1.3 (2010), 94-112.

http://ejournals.library.ualberta.ca/index.php/TC

Of course, this poem is of particular interest to us because it is a description of Chinese chanting. The description of "clear, nasal monosyllables" appears almost verbatim in her essay on the subject, and though she is here describing the chanting of the classics, rather than poetry, I think "the flowering of thought" is an apt epithet for the effect of the tunes she and Peggy transcribed (or at least the first one). It is unfortunate that we do not know whether the scene recounted in this poem inspired her experiment with poetry chants, or if the poetry chants came first - or even, most scandalously, if one of our two tunes was in fact derived from a reading by the "scoundrel" in this poem! ${ }^{10}$ She closes on a plain, ascetic note: "I listen attentively...". To the sound, to what is directly accessible to her perceptions. But how to make sense of those perceptions? As is her habit in these poems, she drifts off in ellipsis.

The irony is carried on in the fourth poem, "Chinese New Year", which describes the purchase of a new "kitchen-god" by a certain Mrs. Sung and her ritual burning of the old one, first smearing his mouth with sugar so that his report to heaven will be favorable (47). This poem, and others like it in Profiles from China, borders on direct reportage, slices of Chinese customs and daily life. There is no sarcasm. The irony is held in place by the poet's obvious distance ('alienation') from the events she narrates. "So there is rejoicing in the house of Mrs. Sung” reads the final line of this poem. But little rejoicing for Eunice Tietjens.

In the final poem we have a slight twist, as we do witness there a more animated poet. "The Most-Sacred Mountain” is an account of her ascent of Mt. Tai, a holy mountain closely associated with Confucius, who lived near it. Tietjens was an avid hiker and she is exuberant

10 We may also wonder how she came to deem this man a "scoundrel". We do not know, but Tietjens's memoir shows that via her sister and the other long-term western residents in Wuxi she was able to understand some of the background of the Chinese people she met there. For instance, one of her poems ("The Feast", Profiles 2829 ) is an ominous account of a bride's wedding day. In The World at My Shoulder, (107-08), Tietjens recounts the circumstances of the marriage and of the bride's subsequent beating at the hands of her mother-in-law. 
TranscUlturAl, vol.1.3 (2010), 94-112.

http://ejournals.library.ualberta.ca/index.php/TC

here, standing at the peak and surveying "the floor of the earth ... stretch[ing] away into blue infinity": "The rhythm ceases here. Time has no place. This is the end that has no end". A bit of cool wit slips in only when she takes note of a nearby stone inscribed with a record of Confucius's famous pronouncement when he visited the peak, that he stood there and "felt the smallness of the world below". She comments:

The stone grows old.

Eternity

Is not for stones. (40)

That is, she finds it an empty monument. Taking her own joy in this peak, she has no need for the words of Confucius, for Chinese culture's particular confirmation of the universal truth she has just experienced.

The poem closes with Tietjens's reflections on her mountain ecstasy. When her mountain joy must come to an end, she

... shall go down from this airy space, this swift white peace, this stinging exultation;

And time will close about me, and my soul stir to the rhythm of the daily round.

Yet, having known, life will not press so close, and always I shall feel time ravel thin about me:

For once I stood

In the white windy presence of eternity.

To feel "time ravel thin" about one: this is what some of Tietjens's contemporaries sought and found in Chinese poetry, and in the artistic culture of the Far East generally. Tietjens seems to have found it there as well, but only when she found her way to familiar alpine territory, a place where she and the Chinese were equally "alien".

\section{The limits of sound and sense}

Translation is always partly a matter of assumptions, even if attempts are made to justify them. What should the poem sound like? How is its sense best represented? The truth is that we can never know, and any answer is bound to be based on a set of assumptions that others are likely to disagree with. Herbert Giles assumed that Chinese poetry should be put into a 
TranscUlturAl, vol.1.3 (2010), 94-112.

http://ejournals.library.ualberta.ca/index.php/TC

form amenable to the nineteenth century English gentleman. Few today would agree with him. Ezra Pound assumed that some aesthetic element could be distilled and amplified from poetry that he understood at second-hand, and imperfectly. Many today will still find inspiration in his example. Arthur Waley, a careful scholar fed up with the assumptions of his day, gave a deliberately limited view of his subject. The merits of his attempt remain debatable.

Eunice Tietjens was in this respect rather like Waley, unimpressed with the assumptions being made about China and Chinese poetry and eager to establish some limits on them. This was a decidedly anti-romantic position, precisely the sort that Wordsworth, addressing Coleridge, had condemned:

... Thou art no slave

Of that false secondary power by which,

In weakness, we create distinctions, then

Deem that our puny boundaries are things

Which we perceive, and not which we have made. (84; 1805 ed. 2.220-24)

Tietjens's interest was precisely in those "puny boundaries" that are the real matter of perception, at least by mortals not seized with rapture. Her poems expose her own "weakness" as much as they do any picture of the China she visited.

At times Tietjens seems to have penetrated through those boundaries, to what Wordsworth goes on to praise as the "unity of all" (2.226). This may be the accomplishment of the first of her transcriptions of Chinese chanting, and of the ecstatic mountain vision in her poem at Mount Tai. But even there, Tietjens's focus was on her perceptions. 'Listening attentively', she tried to capture the sound of the poetry, as she heard it, in her musical transcriptions. Likewise, in her own poetry she sought to represent the sense of China, as she sensed it. This is not just a presentation of her experience. It is a meta-presentation, of her experience as she experienced it, such that in her music we hear not the sound of a Chinese poem but the pursuit 
TranscUlturAl, vol.1.3 (2010), 94-112.

http://ejournals.library.ualberta.ca/index.php/TC

of that sound, successful or no, and in her poetry we see not a simple 'sketch' of China as it was but the distance of the hand that did the sketching, of the mind that did the perceiving. This is useful to keep in mind when we read translations that stake some claim to the sound and sense of Chinese poetry, for Tietjens exposes the distance that is always hidden there. 
TranscUlturAl, vol.1.3 (2010), 94-112.

http://ejournals.library.ualberta.ca/index.php/TC

\section{REFERENCES}

Giles, Herbert A. Chinese Poetry in English Verse. London: Bernard Quaritch, and Shanghai: Kelly and Walsh, 1898.

Huang, Yunte. Transpacific Displacement: Ethnography, Translation, and Intertextual Travel in Twentieth-Century American Literature. Berkeley: University of California Press, 2002.

Kern, Robert. Orientalism, Modernism, and the American Poem. Cambridge: Cambridge University Press, 1996.

Lowell, Amy. "An Observer in China". [Review of Tietjens, Profiles from China]. In Poetry: A Magazine of Verse (Chicago, 1912-), Vol. 10 (September 1917), pp. 326-330.

Pound, Ezra. Cathay: Translations by Ezra Pound; for the most part from the Chinese of Rihaku, from the notes of the late Ernest Fenollosa, and the decipherings of the professors Mori and Ariga. London: Elkin Matthews, 1915.

Qian, Zhaoming. The Modernist Response to Chinese Art: Pound, Moore, Stevens. Charlottesville: University of Virginia Press, 2003.

---. Orientalism and Modernism: The Legacy of China in Pound and Williams. Durham N.C.: Duke University Press, 1995.

Sandburg, Carl. “The Work of Ezra Pound”. In Poetry: A Magazine of Verse (Chicago, 1912-), Vol. 7 (February 1916), pp. 249-257.

Tietjens, Eunice. "The Chinese Chanting of the Classics". In Poetry: A Magazine of Verse (Chicago, 1912-) Vol. 9 (October 1916), pp. 35-39.

---. Profiles from China: Sketches in Verse of People \& Things Seen in the Interior. Chicago: Robert Fletcher Seymour, 1917; also New York: Alfred Knopf, 1917, 1919, 1927.

---. The World at My Shoulder. New York: Macmillan, 1938.

Waley, Arthur. A Hundred and Seventy Chinese Poems. London: Constable, 1918; also New York: Alfred Knopf, 1919.

Wordsworth, William. The Prelude: A Parallel Text. Ed. J.C. Maxwell. London: Penguin, 1971, 1986.

Xie, Ming. Ezra Pound and the Appropriation of Chinese Poetry: Cathay, Translation, and Imagism. New York: Garland, 1999.

Yip, Wai-lim. Eqra Pound's Cathay. Princeton: Princeton University Press, 1969.

This work is licensed under a Creative Commons Attribution 3.0 License 